\title{
PENGAYAAN LOGAM BERAT Mn, Co, DAN Cr PADA LATERIT NIKEL DI KABUPATEN KONAWE UTARA, PROVINSI SULAWESI TENGGARA
}

\section{HEAVY METAL ENRICHMENT OF Mn, CO AND Cr ON NICKEL LATERITE IN NORTH KONAWE REGENCY, SOUTHEAST SULAWESI PROVINCE}

\author{
Ronaldo Irzon \\ Pusat Survei Geologi \\ ronaldoirzon18@gmail.com
}

\begin{abstract}
ABSTRAK
Proses pelapukan lebih mudah terjadi pada wilayah beriklim tropis seperti di Indonesia dan meredistribusi kandungan kimia batuan induk. Hasil proses pelapukan batuan ultramafik banyak teridentifikasi di Kabupaten Konawe Utara, Provinsi Sulawesi Tenggara. Proses pengayaan logam-logam berat pada horizon pelapukan di wilayah Konawe Utara merupakan tujuan penelitian ini. Perangkat XRF dan ICP-MS milik Laboratorium Geologi - Pusat Survei Geologi dimanfaatkan dalam pengukuran kadar oksida utama, unsur jarang, dan unsur tanah jarang pada setiap horizon pelapukan dari tiga profil: Andowia, Wawolimbue, dan Marombo. Horizon saprolit di Marombo dianggap layak untuk dijadikan pengganti horizon saprolit di Wawolimbue, karena berasal dari lokasi yang tidak jauh dan sebagai hasil dari pelapukan batuan ultramafik. Dapat disimpulkan bahwa logam berat: Mn, Co dan Cr terkayakan pada horizon laterit relatif terhadap dua horizon pelapukan lainnya, sedangkan Ni tertahan pada transitional bedrock. Pada sisi lain, $\mathrm{Mg}$, $\mathrm{Si}$, dan $\mathrm{Ca}$ cenderung mengalami pengurangan bertahap berbanding lurus dengan proses pelapukan. Profil Wawolimbue dan Marombo sangat mungkin berasal dari batuan induk yang sama dan dipertegas oleh diagram laba-laba unsur tanah jarang. Perbedaan pola diagram unsur tanah jarang berikut derajat anomali Eu menegaskan kesimpulan bahwa profil Andowia berasal dari batuan induk berbeda terhadap profil Wawolimbue-Marombo. Unsur tanah jarang paling terkayakan pada horizon laterit dengan anomali Ce negatif terkait terbentuknya fraksi lempungan dan oksidasi spontan $\mathrm{Ce}^{3+}$ menjadi $\mathrm{Ce}^{4+}$ saat pelapukan.
\end{abstract}

Kata kunci: Konawe Utara, logam berat, profil pelapukan, ultramafik.

\section{ABSTRACT}

Weathering is most heavily occurred in tropical area such as Indonesia which redistributes the elements geochemistry. Weathering profiles of ultramafic rock are identified in North Konawe Regency, Southeast Sulawesi Province. Heavy metals enrichmentprocess in weathered profiles at North Konawe is the topic of this paper. XRF and ICP-MS of Geology Laboratory Center for Geological Survey were applied to measure the major oxides, trace, and rare earth elements content in the weathered horizons at three profiles: Andowia, Wawolimbue, and Marombo. The saprolite horizon in Marombo is considered feasible to be a substitute for the saprolite horizon at Wawolimbue because it comes from a nearby location and as weathering result of ultramafic rock. Mn, Co and Cr are enriched mostly in laterite of the two profiles relative to two other weathered horizons whilst Ni is concentrated in transitional bedrock. On the other hand, Mg, Si, and Ca are depleted gradually along weathering process. The Wawolimbue and Marombo profiles are very likely derived from the same parent rocks supported by their similarity of REE spider diagrams. The differences in REE spider diagram patterns and the degree of Eu anomaly confirm the conclusion that the Andowia profile is derived from different 


\section{MAKALAH ILMIAH}

parent rocks against the Wawolimbue-Marombo profile. Highest REE concentrations are detected in lateritic horizon together with negative $\mathrm{Ce}$ anomaly in relation to clayish fraction and spontaneous oxidation of $\mathrm{Ce}^{3+}$ into $\mathrm{Ce}^{4+}$ in weathering process.

Keywords: heavy metals, North Konawe, ultramafic, weathering profiles.

\section{PENDAHULUAN}

Penelitian mengenai proses pelapukan terhadap pembentukan laterit telah menjadi topik menarik yang dipelajari terkait dengan ragam batuan induk. Pelapukan pada batuan merupakan satu proses penting yang mengakibatkan redistribusi unsur kimia dan dipengaruhi oleh beragam faktor, seperti: topografi, jenis batuan induk, iklim setempat, dan aktifitas biologi (Calagari drr., 2015). Horizon laterit merupakan salah satu jenis lapisan yang dihasilkan akibat pelapukan batuan induk selain saprolit. Secara megaskopis batuan induk masih dapat dikenali pada horizon saprolit, sedangkan tipikal batuan induk sulit untuk diketahui jika hanya melihat pada horizon laterit (Irzon drr., 2016). Horizon tanah penutup juga merupakan hasil pelapukan, namun telah terganggu oleh keterdapatan bahan-bahan organik. Laterit sebagai produk dari pelapukan diduga berjumlah melebihi $85 \%$ dari lapisan tanah di dunia (Jianwu, 2013). Horizon ini sangat mudah tererosi dan terpindahkan menuju laut, oleh karena itu pemahaman mengenai laterit akan membantu menggambarkan mekanisme pelapukan dan menjelaskan mengenai rekaman kimia pada sedimen dan tanah (soil). Studi mengenai proses laterisasi di wilayah Zan, Iran menyimpulkan bahwa selama pembentukan laterit telah terjadi pengurangan silika, alkali, dan unsur alkali bumi meski terdapat adanya pengayaan Al dan Fe (Calagari drr., 2015).

Pulau Sulawesi merupakan tempat tumbukan aktif dari tiga lempeng yaitu Lempeng Hindia-Australia yang bergerak relatif ke arah utara, Lempeng Samudera
Pasifik bergerak relatif ke barat, dan Lempeng Benua Eurasia yang relatif diam, sehingga mempunyai struktur geologi dan stratigrafi yang rumit, serta komposisi batuan yang beragam (Villenueve drr., 2002 dalam Alam drr., 2012). Konawe Utara merupakan salah satu kabupaten di Provinsi Sulawesi Tenggara dan berlokasi pada lengan tenggara Pulau Sulawesi (Gambar 1). Batuan ultramafik banyak tersingkap pada wilayah yang merupakan bagian dari Kawasan Strategis Nasional Soroako terkait dengan kandungan nikelnya. PT Kembar Mas Sutra, PT Elit Karisma Modern, PT Konutara Sejati, PT Karya Tama Konawe Utara, dan PT Cinta Jaya adalah lima perusahaan penambangan nikel yang berkomitmen untuk melanjutkan penambangan nikel dengan melakukan pembangunan smelter untuk pengolahannya (Irzon dan Baharuddin 2016). Krom, nikel, kobalt, dan mangan merupakan kelompok logam yang berkorelasi dengan batuan ultrabasa selain besi dan magnesium (Hariri, 2004; Heggie drr., 2013; Kumar dan Maiti, 2013). Karena terletak di sekitar garis khatulistiwa, Konawe Utara beriklim tropis dengan curah hujan melebihi $1.500 \mathrm{~mm}^{3}$ pada tahun 2012 (Anonim, 2013). Kondisi alam yang demikian tentu membantu proses pelapukan batuan sehingga terbentuk horizon-horizon pelapukan: saprolit dan laterit. Bijih laterit telah terbukti mengandung banyak logam ekonomis seperti: $\mathrm{Fe}, \mathrm{Co}, \mathrm{Mn}, \mathrm{Mg}$, dan Ni (Gao drr., 2014). Laterit pada batuan ultramafik menghasilkan kadar nikel yang terbukti lebih besar dari pada batuan induknya, seperti telah diteliti di Motui, Konawe Utara (Chaerul drr., 2015). 


\section{MAKALAH ILMIAH}
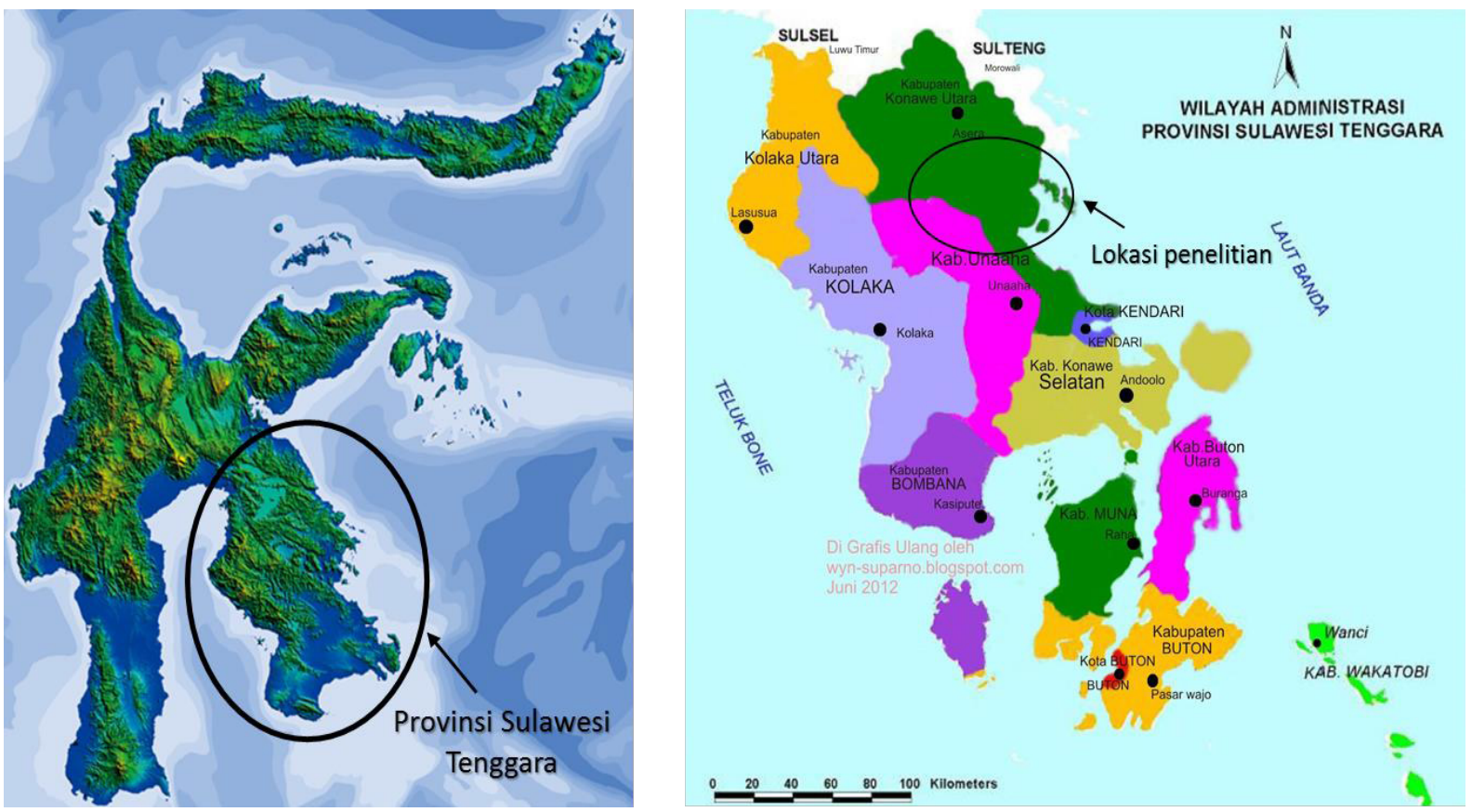

Gambar 1. Wilayah penelitian yang berada di wilayah Kabupaten Konawe Utara, Provinsi Sulawesi Tenggara

Penelitian ini membahas mengenai pengayaan logam-logam berat pada horizon laterit di wilayah Konawe Utara. Pemahaman tentang mobilisasi logam berat saat pelapukan batuan ultramafik dapat membantu mengarahkan kegiatan eksplorasi menuju tahap eksplorasi selanjutnya hingga tahap eksploitasi logam tersebut. Batuan ultramafik memang bukan domain utama dari unsur tanah jarang seperti yang dijabarkan oleh Castor dan Hedrick (2006). Namun demikian, mobilisasi kelompok unsur tersebut turut dipelajari pada studi yang merupakan bagian dari proyek Pusat Survei Geologi bertema batuan ultramafik di Konawe Utara pada tahun 2014. Karena batuan induk tidak tersingkap pada profil yang diteliti, kadar unsur dalam batuan induk mengacu pada hasil penelitian terdahulu mengenai batuan ultramafik di kabupaten yang sama (Irzon dan Baharuddin, 2016) seperti tertera pada Tabel 1a.

\section{METODOLOGI}

\section{Pengambilan Conto Pada Setiap Profil Pelapukan}

Conto pada studi ini berasal dari profil laterit nikel yang berada di Kabupaten Konawe
Utara. Profil pertama berada di sekitar Andowia berupa hasil pelapukan batuan ultramafik dengan ketebalan $3 \mathrm{~m}$. Horizon saprolit, laterit, dan top soil dapat diamati pada profil KUR 57 ini. Saprolit dengan tipikal relatif lebih keras merupakan deskripsi KUR 57-D dengan ketebalan $1 \mathrm{~m}$ dan kemudian ditutupi oleh saprolit lebih mudah hancur yang berbatas dengan laterit sebagai KUR $57-\mathrm{C}$ (tebal $\approx 0,5 \mathrm{~m}$ ). Jarak antara horizon laterit ke bagian bawah horizon soil adalah sekitar 1,5 m. Laterit pada profil ini berwarna merah gelap yang diduga sebagai hasil pelapukan besi. Mineral lempungan juga dapat diamati pada horizon KUR 57-B tersebut. Top soil secara megaskopis masih berwarna merah gelap meski tanpa mineral lempungan dan masih dijumpai akar-akar tanaman. Tebal horizon paling atas ini mencapai setengah meter (KUR 57-A).

Profil kedua berada dekat tepi jalan raya di wilayah Wawolimbue dengan ketinggian sekitar $3 \mathrm{~m}$. Tak terdapat horizon saprolit pada profil KUR-158 ini. Horizon paling bawah merupakan laterit dengan warna merah keabuan dengan ketebalan $1 \mathrm{~m}$ (KUR158-C) yang menutupi horizon diatasnya sebagai laterit dengan warna lebih gelap (KUR158-B, ketebalan $1 \mathrm{~m}$ ). Iron 
crusts dapat diamati terdapat pada horizon tengah di profil ini. Soil yang masih mengandung bahan karbon dan tercampur dengan laterit pada profil ini berketebalan 1 m (KUR 158-A). Tidak dapat diamati horizon saprolit pada profil tersebut.

Pada titik pengamatan di Marombo (KUR 157), berjarak $1,4 \mathrm{~km}$ dari lokasi KUR 158 dan terpisahkan oleh area pertanian, tersingkap dua horizon hasil pelapukan batuan ultramafik. Kemiringan lereng yang cukup terjal di KUR 157 ini cukup menyulitkan proses pengambilan conto. Horizon paling bawah tampak cukup tebal (sekitar $3 \mathrm{~m}$ ) dengan ciri batuan induk masih dapat dikenali sehingga dapat dikategorikan sebagai saprolit. Namun demikian, horizon paling atas pada profil di Marombo relatif lebih sukar diambil dan terdapat lepasanlepasan batuan yang sangat mungkin berasal dari lokasi berbeda. Kedua faktor tersebut dijadikan dasar bahwa horizon paling atas di Marombo tidak representatif untuk dibahas dalam proses pelapukan. Keadaan profil penelitian dapat diamati pada Gambar 2. Akan tetapi, karena berasal dari lokasi yang tidak jauh dan sebagai hasil dari pelapukan batuan ultramafik, horizon saprolit di Marombo dianggap layak untuk dijadikan pengganti horizon saprolit di Wawolimbue. Kondisi tiga profil hasil pelapukan ultramafik pada studi ini telah disederhanakan pada Gambar 3.

\section{Analisis Laboratorium}

Conto yang diperoleh kemudian dianalisis di Laboratorium Kimia Pusat Survei Geologi. Studi ini memanfaatkan dua instrumen, yaitu: $X$-Ray Fluorescence (XRF) dan Inductively
Coupled Plasma-Mass Spectrometry (ICP$\mathrm{MS})$. Perangkat tipe Advant XP merupakan model perangkat XRF pada studi ini, sedangkan ICP-MS menggunakan model XSeries dari Thermo. Di laboratorium, conto dikeringkan di bawah panas matahari tanpa proses pencucian seperti yang diaplikasikan pada conto hard rock, karena akan merusak. Conto digerus hingga ukuran butir 200 mesh untuk memudahkan proses destruksi karena luas bidang reaksi berbanding lurus dengan kecepatan reaksi.

Satu gram conto yang telah dibentuk menjadi pressed pellets kemudian dianalisis menggunakan XRF untuk mengetahui kandungan oksida utama dan jarang $\left(\mathrm{SiO}_{2}\right.$, $\mathrm{Al}_{2} \mathrm{O}_{3}, \mathrm{~K} 2 \mathrm{O}, \mathrm{Fe}_{2} \mathrm{O}_{3}, \mathrm{Na}_{2} \mathrm{O}, \mathrm{CaO}, \mathrm{MgO}, \mathrm{NiO}$, $\mathrm{Cr}_{2} \mathrm{O}_{3}, \mathrm{SO}_{3}, \mathrm{TiO}_{2}, \mathrm{MnO}, \mathrm{ZnO}$ dan $\mathrm{Co}_{3} \mathrm{O}_{4}$ ). Kadar Loss on Ignition (LOI) diukur untuk mengetahui jumlah bahan volatil pada conto seperti senyawa hidrat, senyawa hidroksi, dan karbon dioksida. Hanya 0,1 gram conto yang diperlukan untuk kemudian didestruksi dengan tiga jenis asam sebelum analisis ICP-MS, yakni: asam nitrat $\left(\mathrm{HNO}_{3}\right.$, ultra pure), asam formiat $(\mathrm{HCOOH}$, ultra pure), dan asam perklorat $\left(\mathrm{HClO}_{4}\right.$, pro analysis). Larutan blanko dan lima tingkat larutan kalibrasi (masing-masing: 0,1 ppb, $1 \mathrm{ppb}, 5$ $\mathrm{ppb}, 10 \mathrm{ppb}$, dan $50 \mathrm{ppb}$ ) dipersiapkan untuk kemudian dianalisis bersama dengan conto terpilih. Penelitian ini membutuhkan dua jenis larutan kalibrasi untuk dapat menganalisis 19 unsur pada conto. Kadar unsur pada delapan conto dari Kabupaten Konawe Utara didapat dengan perbandingan count per second (CPS) pada seri larutan kalibrasi terhadap larutan conto yang telah terkomputasi dalam sistem. 


\section{MAKALAH ILMIAH}

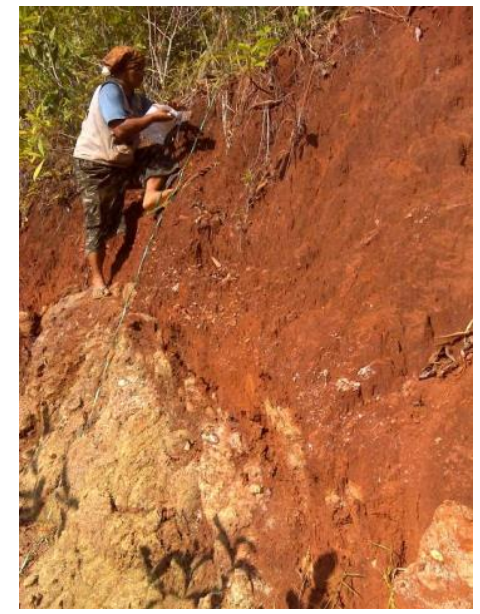

(a)

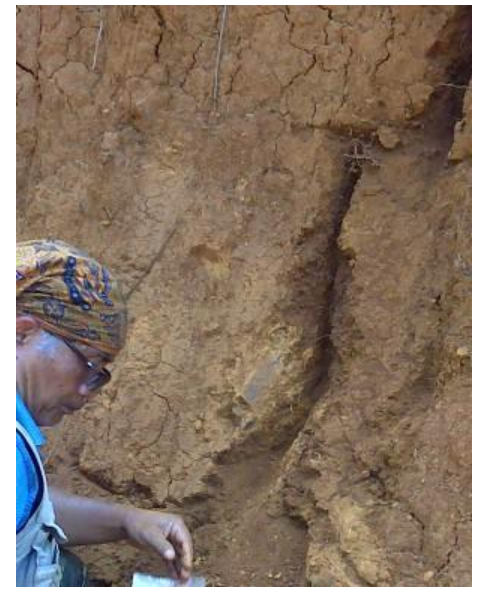

(d)

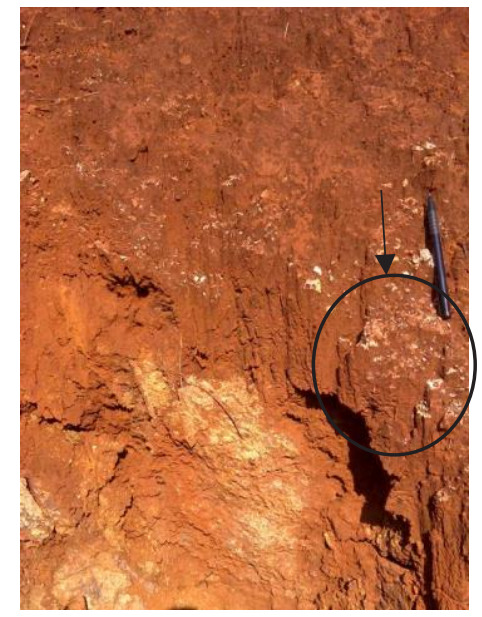

(b)

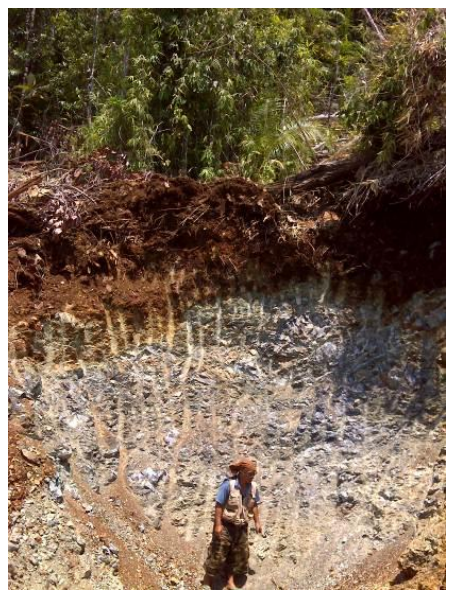

(e)

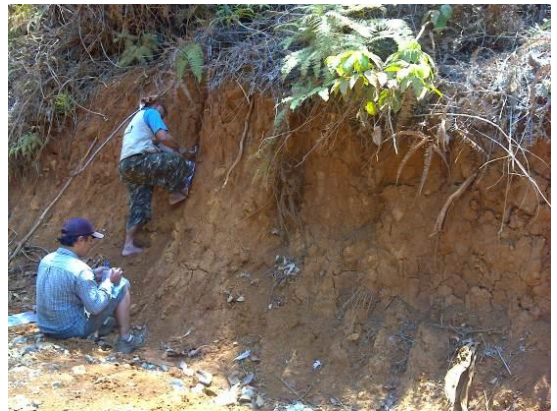

(c)

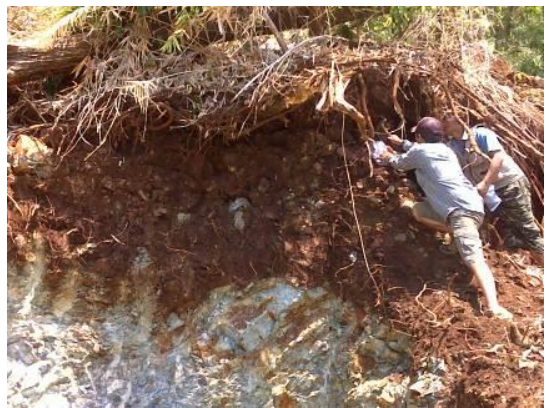

(f)

Gambar 2. a) Profil KUR 57 yang berada di Andowia; b)mineral lempung pada horizon laterit di KUR 57; c)horizon laterit yang dapat dibagi menjadi dua berdasarkan kenampakan warna; d) iron crust yang terdapat pada horizon tengah KUR 158; e) Keadaan lokasi KUR 157; dan f)banyak lepasan batuan pada horizon paling atas di Marombo sehingga tidak sesuai untuk membahas pelapukan

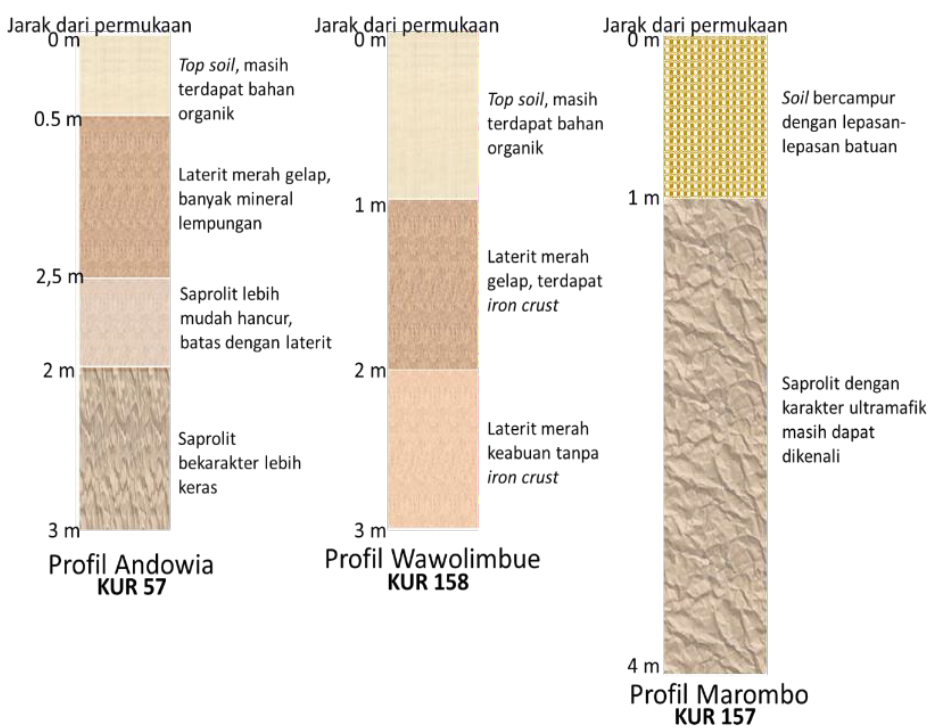

Gambar 3. Sketsa profil penelitian di Andowia, Wawolimbue, dan Marombo 


\section{GEOLOGI}

Hampir seluruh lengan tenggara Pulau Sulawesi terdapat di daerah Provinsi Sulawesi Tenggara. Provinisi ini dipotong oleh beberapa lajur sesar yang berarah baratluat- tenggara, yakni: Lasolo, Matano, Kolono, dan Kolaka (Charlton, 2000). Kabupaten Konawe Utara berada pada bagian utara dari Peta Geologi Lembar Lasusua-Kendari, Sulawesi (Rusmana drr., 2010). Sesar Lasolo merupakan sesar geser yang membagi daerah Kendari menjadi dua lajur, yaitu: Tinondo dan Hialu. Batuan berafiliasi paparan benua merupakan ciri Lajur Tinondo yang berada di wilayah baratdaya. Pada sisi lain, Lajur Hialu menempati daerah timurlaut dengan himpunan batuan yang berasal dari kerak samudera (Syafrizal drr., 2011).

Satuan batuan beku, batuan sedimen, dan batuan malihan dapat dijumpai pada Lembar Geologi Lasusua-Kendari (Rusmana drr., 2010). Satuan batuan tersebut secara berurutan dari tua ke muda adalah: Batuan Malihan Palezoikum, Pualam Palezoikum, Batuan Terobosan, Formasi Tolaka, Formasi Meluhu, Batuan Ofiolit, Formasi Matano, Formasi Salodik, Formasi Pandua, Formasi Alangga, Terumbu Koral Kuarter dan Aluvium. Lokasi penelitian berada pada Kompleks Ofiolit yang diperkirakan terbentuk pada Periode Kapur dan terdiri dari peridotit, harzburgit, dunit, gabro, dan sepentinit. Kompleks Ofiolit yang tersingkap di Kabupaten Konawe Utara lebih menunjukkan afinitas OIB (Ocean Island Basalt) dari pada MORB (Mid-Ocean Ridge Basalt) berdasarkan pada kandungan kimia yang digambarkan dalam diagram laba-laba unsur jarang maupun tanah jarang (Irzon dan Baharuddin, 2016). Kondisi geologi wilayah Konawe Utara tertera pada Gambar 4.

\section{HASIL DAN PEMBAHASAN}

\section{HASIL}

Dari ketiga profil laterit nikel yang dipelajari, telah diambil delapan conto. Kandungan oksida utama diketahui dengan penggunaan perangkat XRF. Pada sisi lain, ICP-MS dimanfaatkan untuk mengukur kadar unsur jarang dan unsur tanah jarang. Hasil pengukuran kandungan kimia conto terpilih terangkum pada Tabel $1 \mathrm{~b}$.

\section{PEMBAHASAN}

\section{Pengayaan Logam Berat Pada Horizon Laterit}

Purwanto dan Agustini (2014) menjelaskan bahwa proses mineralisasi laterit secara kimia disebabkan oleh ketidakseimbangan air dekat permukaan, pengaruh temperatur, dan aktifitas biologi yang akan menghasilkan mineral baru yang berbeda dari asalnya. Pada tahap awal batuan induk terlapukkan pada daerah sekitar kekar yang akan melepaskan serpentin menjadi talk (lempung), air, dan ion Mg (Ahmad, 2006). Batuan induk ultramafik di Konawe Utara secara umum berwarna abu-abu gelap, berbutir halus hingga sedang, dan tersusun oleh limpahan mineral olivin $(\mathrm{Mg}, \mathrm{Fe})_{2} \mathrm{SiO}_{4}$ dan piroksen $\left(\mathrm{Ca}(\mathrm{Mg}, \mathrm{Fe}) \mathrm{Si}_{2} \mathrm{O}_{6}\right.$ ) (Irzon dan Baharuddin, 2015). Pelapukan akan melapaskan ion $\mathrm{Mg}-\mathrm{Fe}$ dari olivin dan $\mathrm{Mg}$ $\mathrm{Fe}-\mathrm{Ca}$ dari piroksen selain juga akan membentuk mineral residu berupa oksidaoksida $\mathrm{Fe}$ seperti hematit $\left(\mathrm{Fe}_{2} \mathrm{O}_{3} \mathrm{~T}\right)$ dan goethite $(\mathrm{FeOOH})$.

Pada titik pengamatan di Andowia dapat dilihat adanya sedikit penurunan kadar Fe oksida dari horizon saprolit menuju batas antara saprolit dan laterit. Namun demikian, besi oksida naik sangat signifikan, hingga lebih dari lima kali lipat, pada horizon laterit bagian atas maupun pada horizon tanah (soil). Kenaikan kadar $\mathrm{Al}_{2} \mathrm{O}_{3}$ dari horizon paling bawah ke paling atas secara bertahap teramati pada lokasi KUR 57 ini, dengan kadar masing-masing 2,96\%, 3,14\%, 5,54\%, dan $7,4 \%$ pada saprolit, batas saprolit-laterit, laterit, dan tanah (soil) (Gambar 5a). Peningkatan cukup tinggi berbanding lurus dengan tingkat pelapukan dapat diamati pada empat jenis logam berat: $\mathrm{Mn}, \mathrm{Cr}, \mathrm{Ti}$, dan Co (Gambar 6a dan Gambar 7a). Namun demikian, terdapat kecenderungan pola menurun untuk oksida-oksida logam lain, yaitu: $\mathrm{Si}, \mathrm{Mg}, \mathrm{Ni}$, dan $\mathrm{Ca}$ terhadap 
derajat pelapukan. Meski kadar $\mathrm{MgO}$ tertinggi terdapat pada horizon batas saprolit-laterit $(28,47 \%)$, kandungannya kemudian jauh menurun hingga 2,28\% (laterit) dan 1,3\% (soil). Mg termasuk kation dengan mobilitas tinggi dan mudah larut saat proses pelapukan sehingga kadarnya akan berkurang sejalan dengan proses pelapukan. Mobilitas tinggi $\mathrm{Mg}$ berbanding terbalik dengan $\mathrm{Al}_{2} \mathrm{O}_{3}$ yang justru memiliki derajat mobilitas rendah dan kemudian meningkat kadarnya selama pelapukan (Alam drr., 2012). Pola mobilisasi dari horizon paling segar menuju paling lapuk pada $\mathrm{Ni}$ hampir serupa dengan $\mathrm{MgO}$. Pola tersebut menggambarkan bahwa setelah terjadinya co-presipitasi Ni-Co-Mn pada tahap awal lateritisasi, nikel kemudian tercuci keluar dari horizon laterit dan bermigrasi menuju horizon saprolit yang kemudian tertahan pada horizon yang disebut sebagai transitional bedrock (Purwanto dan Agustini, 2014). Proses pelapukan pada batuan ultramafik di Kepulauan Solomon (Sagapoa drr., 2011) dan Goias - Brazil (Ratie drr., 2015) juga menunjukkan kecenderungan serupa.

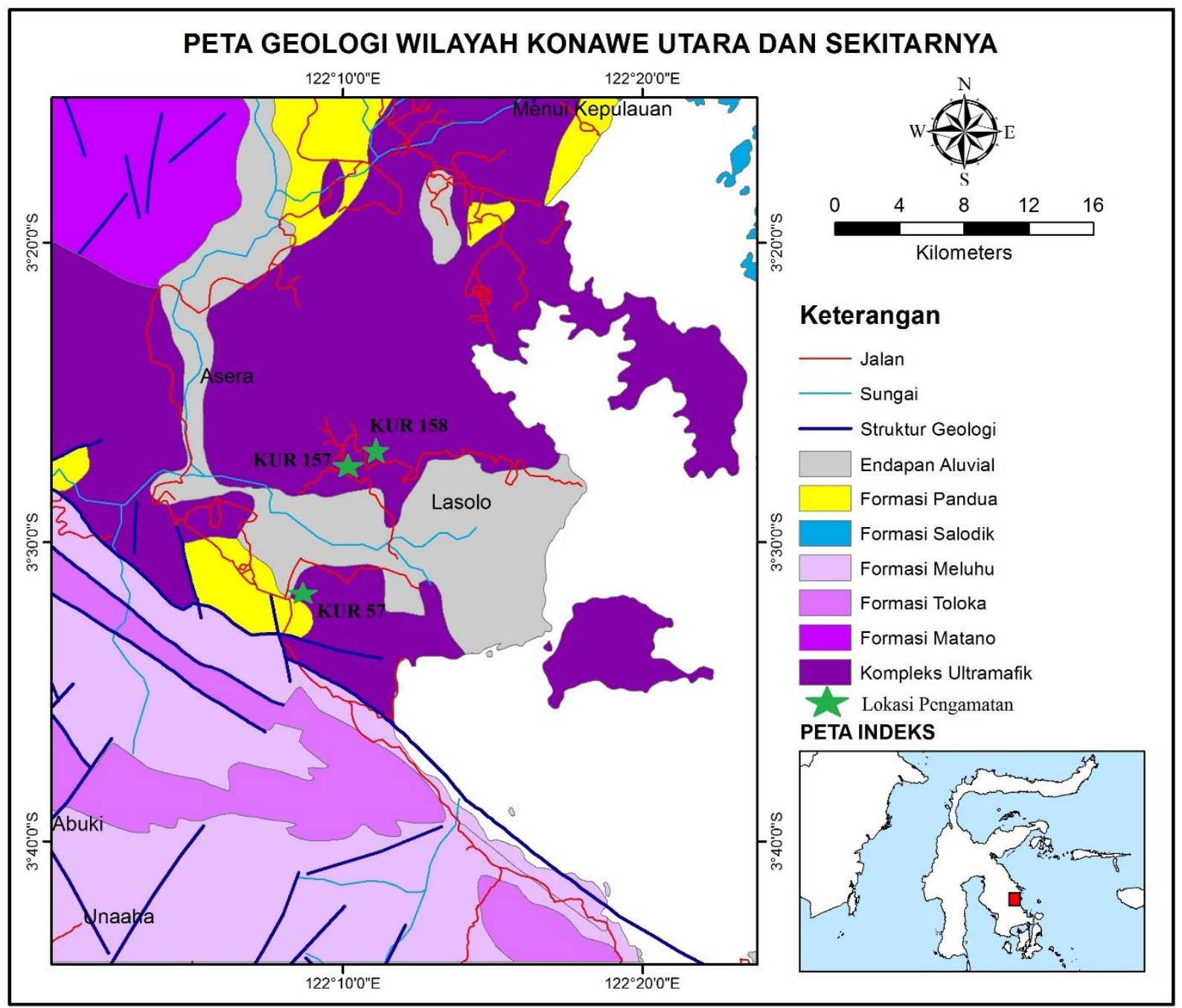

Gambar 4. Titik lokasi pengamatan dan kondisi geologi di Kabupaten Konawe Utara (dimodifikasi dari Rusmana drr., 1993) 
Tabel 1. a) Hasil analisis geokimia pada batuan ultramafik di Konawe Utara (sumber: Irzon dan Baharuddin, 2016); dan b) Kandungan geokimia conto terpilih dari dua a) profil laterit nikel Konawe Utara.

)

\begin{tabular}{|c|c|c|c|c|c|c|c|c|c|}
\hline & KUD 02 & KUD 05 & KUD 06 & $\begin{array}{c}\text { KUD } \\
50 A \\
\end{array}$ & KUD 51 & KUD 54 & KUD 56 & $\begin{array}{c}\text { KUD } \\
154 \\
\end{array}$ & KUD 156 \\
\hline \multicolumn{10}{|c|}{ Oksida Utama (\%) } \\
\hline $\mathrm{SiO}_{2}$ & 38,96 & 38,48 & 38,58 & 38,5 & 40,05 & 39,08 & 39,25 & 39,41 & 41,07 \\
\hline $\mathrm{TiO}_{2}$ & 0,0086 & 0,148 & 0,0345 & 0,0349 & 0,0714 & 0,0134 & 0,0108 & 0,0117 & 0,112 \\
\hline $\mathrm{Al}_{2} \mathrm{O}_{3}$ & 0,8 & 3,16 & 1,15 & 1,69 & 2,55 & 1,02 & 0,83 & 0,98 & 2,92 \\
\hline $\mathrm{Fe}_{2} \mathrm{O}_{3} \mathrm{~T}$ & 9,7 & 8,55 & 10,5 & 8,53 & 9,45 & 9,92 & 9,27 & 8,7 & 12,29 \\
\hline $\mathrm{MgO}$ & 43,54 & 36,95 & 43,44 & 42,07 & 41,65 & 41,31 & 44 & 37,39 & 39,31 \\
\hline $\mathrm{CaO}$ & 0,96 & 3,14 & 1,72 & 1,26 & 2,1 & 1,14 & 0,9 & 0,75 & 3,55 \\
\hline $\mathrm{MnO}$ & 0,14 & 0,129 & 0,147 & 0,124 & 0,141 & 0,143 & 0,129 & 0,132 & 0,163 \\
\hline $\mathrm{K}_{2} \mathrm{O}$ & $\mathrm{n}, \mathrm{d}$ & 0,0027 & 0,005 & 0,0029 & $\mathrm{n}, \mathrm{d}$, & 0,004 & 0,0028 & $\mathrm{n}, \mathrm{d}$, & 0,0106 \\
\hline $\mathrm{Na}_{2} \mathrm{O}$ & $\mathrm{n}, \mathrm{d}$ & $\mathrm{n}, \mathrm{d}$, & $\mathrm{n}, \mathrm{d}$ & $\mathrm{n}, \mathrm{d}$, & 0,0708 & $\mathrm{n}, \mathrm{d}$ & $\mathrm{n}, \mathrm{d}$, & $\mathrm{n}, \mathrm{d}$, & 0,15 \\
\hline $\mathrm{NiO}$ & 0,352 & 0,306 & 0,382 & 0,303 & 0,308 & 0,364 & 0,388 & 0,332 & 0,329 \\
\hline $\mathrm{Cr}_{2} \mathrm{O}_{3}$ & 0,35 & 0,304 & 0,363 & 0,34 & 0,36 & 0,362 & 0,298 & 0,335 & 0,425 \\
\hline $\mathrm{CO}_{3} \mathrm{O}_{4}$ & 0,0151 & 0,0155 & 0,0179 & 0,0153 & 0,0164 & 0,0173 & 0,0152 & 0,0149 & 0,0165 \\
\hline $\mathrm{SO}_{3}$ & 0,0415 & 0,057 & 0,0285 & 0,0293 & 0,0387 & 0,0256 & 0,0243 & 0,0173 & $\mathrm{n}, \mathrm{d}$, \\
\hline LOI & 5,08 & 8,66 & 3,59 & 7,05 & 3,16 & 6,56 & 4,85 & 11,88 & 0,16 \\
\hline Jumlah & 99,9472 & 99,9022 & 99,9579 & 99,9494 & 99,9663 & 99,9593 & 99,9681 & 99,9529 & 100,5061 \\
\hline \multicolumn{10}{|c|}{ Unsur jarang dan tanah jarang (ppm) } \\
\hline $\mathrm{V}$ & 57,95 & 29,61 & 47,46 & 50,93 & 118,57 & 83,04 & 51,54 & 78,82 & 94,66 \\
\hline $\mathrm{Rb}$ & 69,85 & 69,57 & 69,72 & 71,99 & 73,32 & 72,08 & 71,07 & 73,05 & 71,82 \\
\hline $\mathrm{Y}$ & 0,4 & 1,86 & 0,62 & 1,01 & 2,31 & 0,44 & 0,62 & 0,27 & 2,53 \\
\hline $\mathrm{Ba}$ & 15,3 & 11,06 & 18,85 & 19,84 & 18,87 & 18,49 & 21,07 & 28,46 & 24,66 \\
\hline La & 0,41 & 0,98 & 0,35 & 0,67 & 0,64 & 0,25 & 0,30 & 0,32 & 0,28 \\
\hline $\mathrm{Ce}$ & 1,17 & 2,35 & 0,87 & 0,85 & 0,90 & 0,63 & 0,72 & 0,72 & 0,82 \\
\hline $\mathrm{Pr}$ & 0,07 & 0,53 & 0,07 & 0,09 & 0,09 & 0,36 & 0,06 & 0,07 & 0,11 \\
\hline $\mathrm{Nd}$ & 0,24 & 1 & 0,26 & 0,30 & 0,42 & 0,16 & 0,19 & 0,22 & 0,48 \\
\hline $\mathrm{Sm}$ & 0,05 & 0,26 & 0,07 & 0,08 & 0,17 & 0,03 & 0,04 & 0,05 & 0,20 \\
\hline $\mathrm{Eu}$ & $\mathrm{n}, \mathrm{d}$ & 0,05 & 0,01 & 0,02 & 0,05 & $\mathrm{n}, \mathrm{d}$, & $\mathrm{n}, \mathrm{d}$, & 0,01 & 0,07 \\
\hline $\mathrm{Gd}$ & 0,05 & 0,31 & 0,10 & 0,12 & 0,25 & 0,06 & 0,07 & 0,06 & 0,29 \\
\hline $\mathrm{Tb}$ & 0,01 & 0,06 & 0,02 & 0,03 & 0,05 & 0,01 & 0,01 & 0,02 & 0,07 \\
\hline Dy & 0,06 & 0,32 & 0,12 & 0,16 & 0,36 & 0,07 & 0,06 & 0,07 & 0,41 \\
\hline $\mathrm{Ho}$ & 0,02 & 0,08 & 0,03 & 0,04 & 0,09 & 0,02 & 0,02 & 0,02 & 0,11 \\
\hline $\mathrm{Er}$ & 0,07 & 0,21 & 0,09 & 0,12 & 0,26 & 0,07 & 0,06 & 0,06 & 0,30 \\
\hline $\mathrm{Tm}$ & 0,01 & 0,03 & 0,01 & 0,02 & 0,04 & 0,01 & 0,02 & 0,02 & 0,06 \\
\hline $\mathrm{Yb}$ & 0,10 & 0,19 & 0,09 & 0,13 & 0,26 & 0,08 & 0,07 & 0,07 & 0,28 \\
\hline Lu & 0,02 & 0,03 & 0,02 & 0,02 & 0,04 & 0,02 & 0,01 & 0,02 & 0,06 \\
\hline Th & 0,41 & 0,25 & 0,01 & 0,1 & 0,07 & 0,38 & 0,14 & 0,5 & 0,29 \\
\hline$U$ & 0,34 & 0,38 & 0,31 & 0,33 & 0,33 & 0,35 & 0,36 & 0,36 & 0,35 \\
\hline$\sum$ UTJ & 2,29 & 6,42 & 2,10 & 2,64 & 3,62 & 1,76 & 1,62 & 1,74 & 3,53 \\
\hline
\end{tabular}


MAKALAH ILMIAH

b)

\begin{tabular}{|c|c|c|c|c|c|c|c|c|}
\hline & $\begin{array}{l}\text { KUR } \\
57-A \\
\end{array}$ & $\begin{array}{l}\text { KUR } \\
57-B \\
\end{array}$ & $\begin{array}{c}\text { KUR 57- } \\
\text { C } \\
\end{array}$ & $\begin{array}{c}\text { KUR 57- } \\
\text { D } \\
\end{array}$ & $\begin{array}{l}\text { KUR } \\
158-A\end{array}$ & $\begin{array}{c}\text { KUR } \\
158-B \\
\end{array}$ & $\begin{array}{c}\text { KUR } \\
158-C \\
\end{array}$ & $\begin{array}{c}\text { KUR } \\
157 \\
\end{array}$ \\
\hline \multicolumn{9}{|c|}{ Oksida Utama (\%) } \\
\hline $\mathrm{SiO}_{2}$ & 20,03 & 36,94 & 38,74 & 39,09 & 10,1 & 10,91 & 8,96 & 29,67 \\
\hline $\mathrm{TiO}_{2}$ & 0,129 & 0,0888 & 0,0458 & 0,0486 & 0,406 & 0,397 & 0,374 & 0,21 \\
\hline $\mathrm{Al}_{2} \mathrm{O}_{3}$ & 7,4 & 5,54 & 3,14 & 2,96 & 11,79 & 11,55 & 11,26 & 7,32 \\
\hline $\mathrm{Fe}_{2} \mathrm{O}_{3} \mathrm{~T}$ & 55,49 & 43,86 & 12,92 & 14,39 & 56,96 & 54,28 & 57,8 & 34,71 \\
\hline $\mathrm{MgO}$ & 1,3 & 2,28 & 28,47 & 26,1 & 0,906 & 1,91 & 1,12 & 6,77 \\
\hline $\mathrm{CaO}$ & 0,0271 & 0,0211 & 0,0806 & 0,0735 & 0,0108 & 0,145 & 0,0243 & 0,538 \\
\hline $\mathrm{MnO}$ & 0,846 & 0,577 & 0,167 & 0,189 & 0,741 & 1,34 & 1,02 & 0,791 \\
\hline $\mathrm{K}_{2} \mathrm{O}$ & 0,0122 & 0,0078 & 0,0052 & 0,0033 & 0,003 & n.a. & n.a & 0.0137 \\
\hline $\mathrm{Na}_{2} \mathrm{O}$ & n.a. & n.a. & n.a. & n.a. & n.a. & n.a. & n.a. & n.a. \\
\hline $\mathrm{NiO}$ & 1,15 & 1,03 & 1,9 & 2,03 & 1,23 & 1,49 & 1,44 & 1,11 \\
\hline $\mathrm{Cr}_{2} \mathrm{O}_{3}$ & 1,99 & 1,56 & 0,616 & 0,622 & 1,72 & 1,79 & 1,77 & 1,34 \\
\hline $\mathrm{Co}_{3} \mathrm{O}_{4}$ & 0,102 & 0,0754 & 0,0188 & 0,0242 & 0,101 & 0,154 & 0,118 & 0,098 \\
\hline $\mathrm{SO}_{3}$ & 0,063 & 0,0472 & 0,0142 & n.a. & 0,0662 & 0,0514 & 0,0666 & 0,0488 \\
\hline $\mathrm{P}_{2} \mathrm{O}_{5}$ & 0,0698 & 0,0455 & n.a. & 0,0028 & n.a. & 0,0217 & 0,0196 & 0,0265 \\
\hline LOI & 11,3 & 8,95 & 13,84 & 14,43 & 15,84 & 15,84 & 15,9 & 17,27 \\
\hline
\end{tabular}

\begin{tabular}{lrlllllll}
\hline Jumlah & 99,9091 & 101,0228 & 99,9576 & 99,9634 & 99,874 & 99,8791 & 99,8725 & 99,916 \\
\hline
\end{tabular}

Unsur jarang dan tanah jarang (ppm)

\begin{tabular}{lrrrrrrrr}
\hline $\mathrm{V}$ & 200,77 & 145,85 & 98,02 & 82,78 & 224,54 & 229,21 & 251,16 & 154,02 \\
\hline $\mathrm{Rb}$ & 73,39 & 71,89 & 71,52 & 71,41 & 69,50 & 67,47 & 66,86 & 68,44 \\
\hline $\mathrm{Y}$ & 1,83 & 4,75 & 1,35 & 1,89 & 9,28 & 14,02 & 12,77 & 4,59 \\
\hline $\mathrm{Ba}$ & 33,12 & 26,40 & 26,31 & 25,05 & 42,44 & 65,46 & 36,34 & 38,07 \\
\hline $\mathrm{La}$ & 0,82 & 1,17 & 0,33 & 1,23 & 1,37 & 1,78 & 1,48 & 0,45 \\
\hline $\mathrm{Ce}$ & 2,81 & 1,60 & 1,04 & 2,86 & 3,35 & 3,51 & 2,88 & 1,29 \\
\hline $\mathrm{Pr}$ & 0,18 & 0,26 & 0,06 & 0,15 & 0,42 & 0,70 & 0,54 & 0,16 \\
\hline $\mathrm{Sm}$ & 0,61 & 0,95 & 0,21 & 0,48 & 1,97 & 3,38 & 2,57 & 0,80 \\
\hline $\mathrm{Eu}$ & 0,14 & 0,23 & 0,07 & 0,13 & 0,74 & 1,28 & 0,97 & 0,33 \\
\hline $\mathrm{Gd}$ & 0,03 & 0,06 & 0,01 & 0,03 & 0,25 & 0,45 & 0,34 & 0,12 \\
\hline $\mathrm{Tb}$ & 0,20 & 0,35 & 0,12 & 0,27 & 1,04 & 1,76 & 1,38 & 0,50 \\
\hline $\mathrm{Dy}$ & 0,04 & 0,07 & 0,03 & 0,05 & 0,23 & 0,39 & 0,30 & 0,12 \\
\hline $\mathrm{Ho}$ & 0,27 & 0,49 & 0,21 & 0,31 & 1,44 & 2,37 & 1,87 & 0,72 \\
\hline $\mathrm{Er}$ & 0,07 & 0,14 & 0,06 & 0,09 & 0,36 & 0,59 & 0,47 & 0,19 \\
\hline $\mathrm{Tm}$ & 0,22 & 0,44 & 0,17 & 0,25 & 1,03 & 1,69 & 1,33 & 0,51 \\
\hline $\mathrm{Yb}$ & 0,04 & 0,07 & 0,03 & 0,06 & 0,17 & 0,27 & 0,21 & 0,09 \\
\hline $\mathrm{Lu}$ & 0,26 & 0,45 & 0,20 & 0,28 & 0,98 & 1,57 & 1,21 & 0,50 \\
\hline $\mathrm{Th}$ & 0,05 & 0,09 & 0,04 & 0,06 & 0,18 & 0,28 & 0,22 & 0,10 \\
\hline $\mathrm{U}$ & 0,36 & 0,19 & 0,04 & 0,21 & 0,38 & 0,25 & 0,30 & 0,17 \\
\hline $\mathrm{LUTJ}$ & 0,40 & 0,37 & 0,35 & 0,37 & 0,40 & 0,37 & 0,37 & 0,34 \\
\hline
\end{tabular}


Sebagian besar oksida utama tidak banyak memperlihatkan perubahan pada profil Wawolimbue. $\mathrm{SiO}_{2}, \mathrm{Al}_{2} \mathrm{O}_{3}, \mathrm{Cr}_{2} \mathrm{O}_{3}, \mathrm{TiO}_{2}$, hingga jumlah material volatil tampak stabil pada rentang $8,96-10,1 \%, 11,26-11,79 \%$, $1,72-1,77 \%$, 0,374-0,406\%, dan 15,84\%$15,9 \%$ secara berurutan (Gambar $5 b$ ). Kondisi demikian sangat mungkin disebabkan oleh proses mobilisasi unsur yang mendekati selesai pada profil ini. Meski demikian, dapat teramati adanya pengayaan $\mathrm{Mg}, \mathrm{Mn}$, dan Co pada horizon laterit dengan adanya iron crust (KUR 158-B) yang masingmasing meningkat $70 \%, 31 \%$, dan $30 \%$ bila dibandingkan dengan kadar pada horizon laterit berwarna coklat terang (158-C). Aluminium crust (bauksit) lebih mudah terbentuk pada iklim tropis lembab, sedangkan iron crust dalam kondisi tropis lembab yang disertai dengan pergantian musim yang kontras (Brown drr., 1994). Iron crust terbentuk pada musim panas dengan lepasnya Fe dari lapisan bagian atas menuju horizon lebih bawahnya. Hal ini menjelaskan mengapa kadar $\mathrm{Fe}_{2} \mathrm{O}_{3 \mathrm{~T}}$ justru lebih rendah pada KUR 158-B $(54,28 \%)$ dibandingkan dengan KUR 158-C (57,8\%). Perbedaan sangat signifikan akan tampak ketika data saprolit Marombo digunakan sebagai pengganti saprolit Wawolimbue. Seperti pada profil Andowia, $\mathrm{SiO}_{2}, \mathrm{MgO}, \mathrm{LO}, \mathrm{CaO}$, dan $\mathrm{Fe}_{2} \mathrm{O}_{3} \mathrm{~T}$ turun secara signifikan dari horizon saprolit (KUR 157) menuju (KUR 158-C). Juga terdapat peningkatan cukup tinggi berbanding lurus dengan derajat pelapukan pada empat jenis logam berat: $\mathrm{Mn}, \mathrm{Cr}$, Ti, dan Co (Gambar 6b dan Gambar 7b). Pengelompokan KUR 157 bukan sebagai batuan induk didukung oleh tingginya kadar LOI $(17,27 \%)$.

Silikat primer (batuan induk) semakin hancur dan kehilangan bentuk selama proses pelapukan yang akan mengawali pembentukan horizon saprolit. Pada rentang masa tersebut juga terjadi proses pertukaran ion seperti: serpentin- $\mathrm{Mg}+\mathrm{Ni}^{2+}=$ serpentinkaya $\mathrm{Ni}+\mathrm{Mg}^{2+}$ (Sagapoa drr., 2011). Silika dan magnesium kemudian tercuci keluar dari horizon paling atas yang dapat pula menjelaskan rendahnya kadar kedua oksida/unsur pada horizon soil. Perubahan kadar unsur selama proses pelapukan turut dikontrol oleh derajat mobilitas yang tergantung pada heterogenitas batuan induk dan pembentukan mineral allorgenik (Chaerul drr., 2015). Telah dijelaskan bahwa semakin tinggi mobilitas unsur akan semakin mempermudah larut dan kemudian menurunkan kadarnya selama pelapukan (Alam drr., 2012). White (2011) merinci bahwa rata-rata derajat mobilitas unsur dari tinggi ke rendah adalah: $\mathrm{Ca}, \mathrm{Mg}, \mathrm{Si}, \mathrm{Ni}, \mathrm{Co} \approx$ $\mathrm{Zn} \approx \mathrm{V}, \mathrm{Fe} \approx \mathrm{Cr} \approx \mathrm{Mn}$. Kemudian, kondisi Eh (aktifitas elektron) dapat memulai copresipitasi $\mathrm{Mn}$ bersamaan dengan $\mathrm{Ni}$, Co, dan beberapa unsur lain. Mn oksihidroksida justru dianggap sebagai pembawa utama pengayaan kobalt dan nikel pada beberapa kasus (Sagapoa drr., 2011). Dengan demikian, derajat mobilitas unsur berikut copresipitasi dapat dianggap sebagai faktor yang menyebabkan pengayaan $\mathrm{Mn}$, Co, dan Cr pada dua profil penelitian. 


\section{MAKALAH ILMIAH}

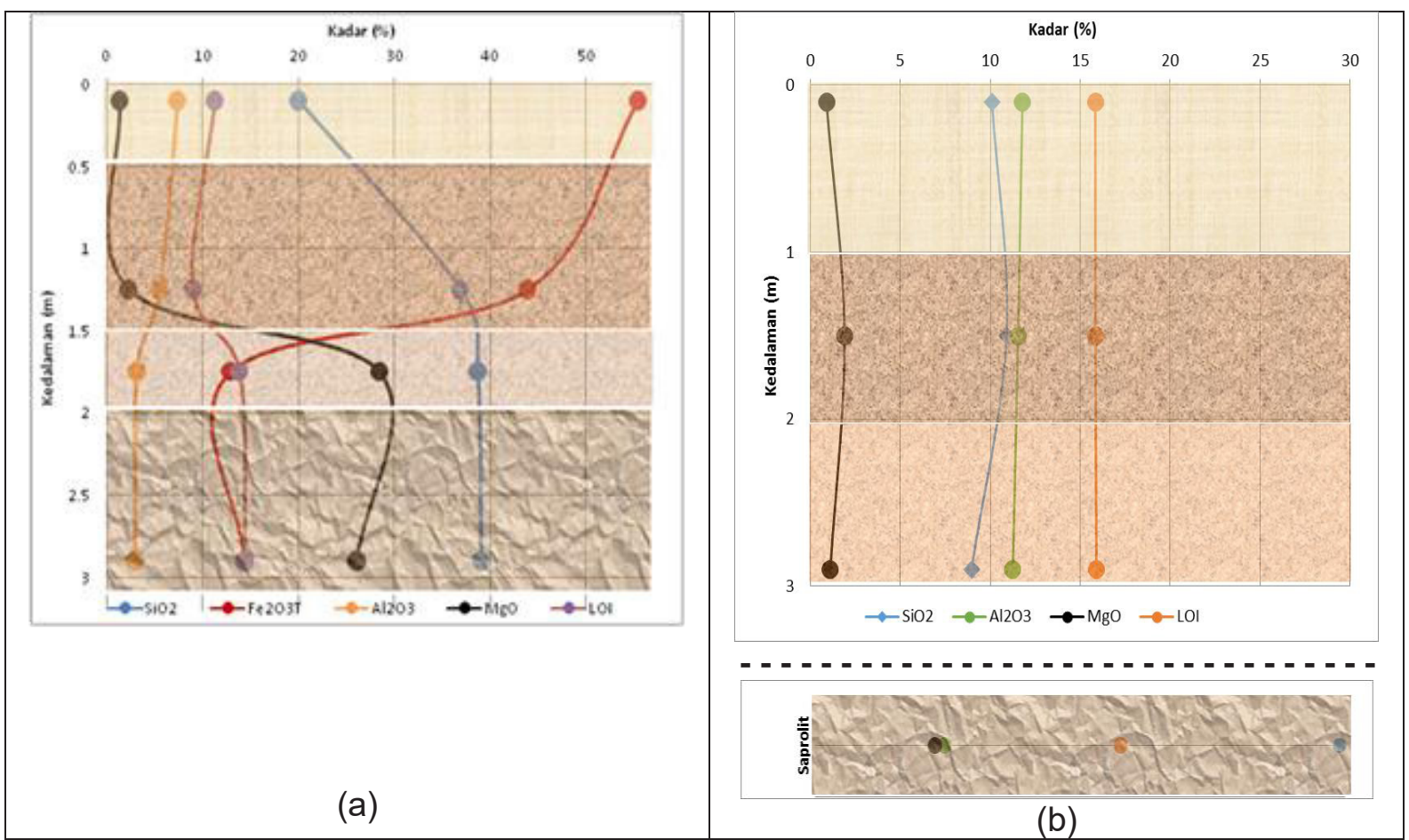

Gambar 5. Perubahan kadar oksida-oksida berkadar besar pada dua lokasi pengamatan: a) Profil Andowia; dan b) Profil Wawolimbue-Marombo.

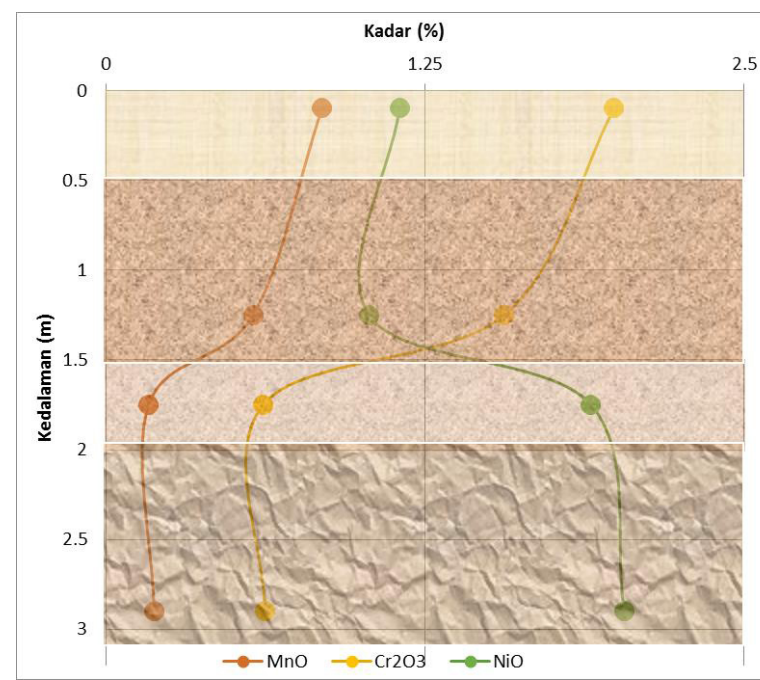

(a)
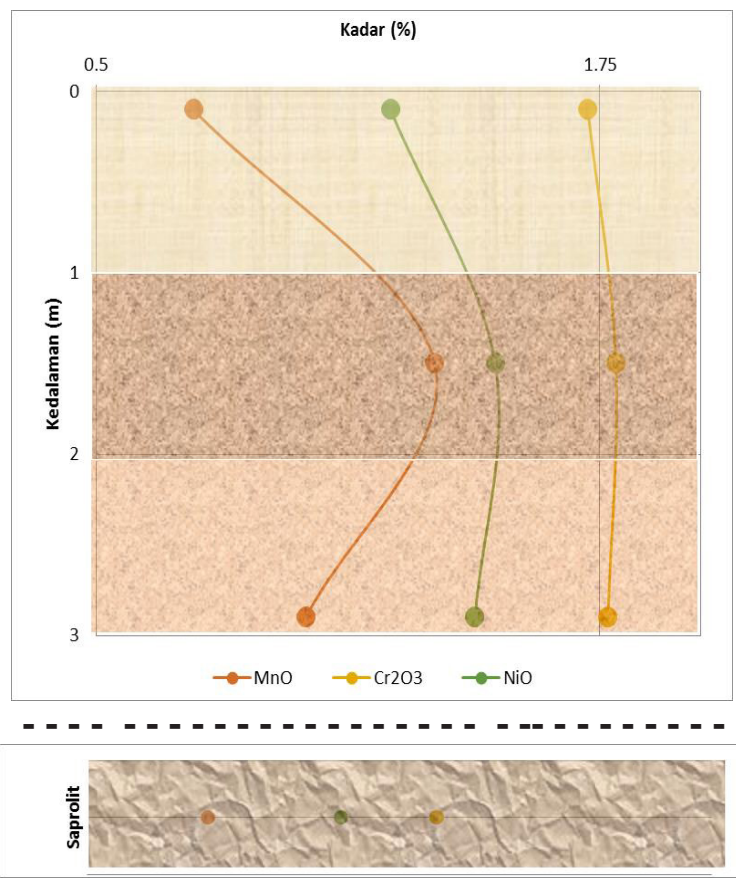

(b)

Gambar 6. Perubahan kadar oksida-oksida berkadar menengah pada dua lokasi pengamatan: a) Profil Andowia; dan b) Profil Wawolimbue-Marombo. 


\section{MAKALAH ILMIAH}

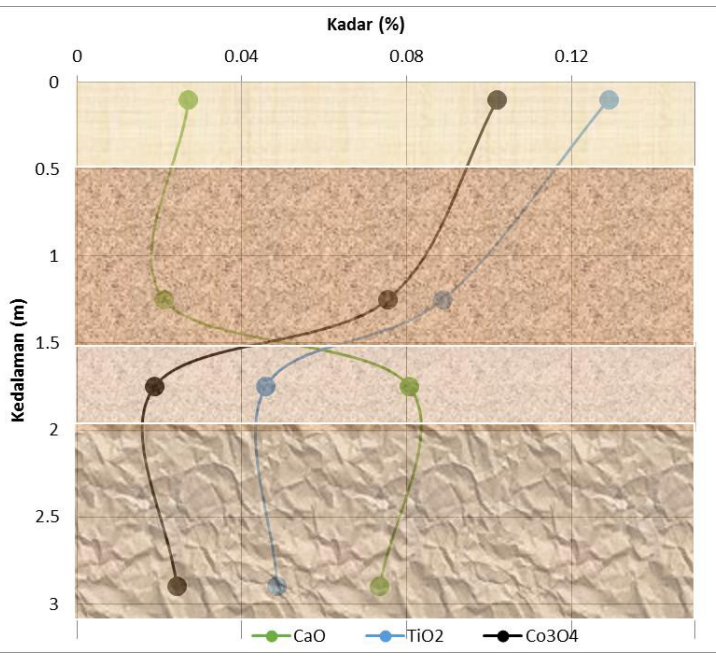

(a)
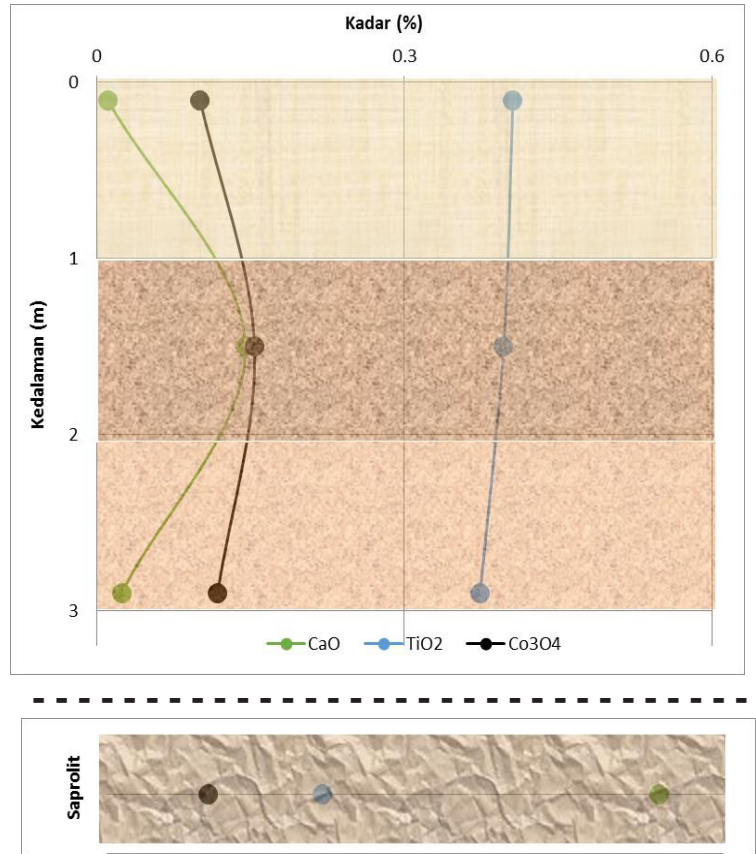

(b)

Gambar 7. Perubahan kadar oksida-oksida berkadar menengah pada dua lokasi pengamatan:

a) Profil Andowia; dan b) Profil Wawolimbue-Marombo.

\section{Perubahan Komposisi Unsur Tanah Jarang}

Vanadium pada horizon relatif lebih segar berkadar 82 ppm (Andowia) dan 154 ppm (Wawolimbue-Marombo) relatif terus meningkat secara gradual seiring kenaikan derajat pelapukan menjadi 200 ppm dan 224 ppm seperti ditunjukkan oleh perubahan komposisi rubidium. Meski kadar barium tertinggi dijumpai pada horizon soil KUR 57, jumlah unsur ini paling banyak terdapat pada horizon laterit gelap di KUR 158. Secara umum, tidak terdapat adanya mobilisasi uranium terkait proses pelapukan pada studi ini. Kesamaan berikutnya pada kedua profil adalah yttrium yang paling terkonsentrasi pada horizon tepat sebelum soil. Unsur tanah jarang dan yttrium tetap terikat pada berbagai kondisi geokimia sehingga dijadikan sebagai indikator yang cocok untuk mempelajari sirkulasi hidrotermal maupun karakter interaksi batuan-air (Bao drr., 2008). Disamping itu konfigurasi elektron maupun radius ion yttrium pun mirip dengan unsur tanah jarang, terutama UTJ-berat, sehingga dapat menjelaskan kesamaan mobilisasi keduanya pada studi ini.
Batuan ultramafik memang bukan merupakan tempat kedudukan utama UTJ (Castor dan Hedrick, 2006), sehingga masih sedikit studi mengenai kedua topik tersebut. Jumlah UTJ pada seluruh conto pada studi ini berkisar antara 2,59 ppm s.d. 20,01 ppm. Namun demikian, studi ini lebih mengarahkan analisis UTJ terhadap mobilisasinya pada pelapukan batuan ultramafik di Konawe Utara. Pola perubahan jumlah kelompok UTJ terhadap berbagai jenis batuan induk terkait proses pelapukan telah dipelajari (seperti: Sagapoa drr., 2011; Mustapha dan Alhassan, 2012; Jianwu drr., 2015; Irzon drr., 2016). Kandungan UTJ pada setiap conto dalam studi ini telah dinormalisasi menggunakan nilai primitive mantle (Sun dan McDonough, 1989) untuk menghilangkan Oddo-Harkins effect seperti ditampilkan pada Gambar 8 untuk Profil Andowia dan Gambar 9 untuk Profil Wawolimbue-Marombo. Diagram laba-laba pada stasiun KUR 57 memperlihatkan bahwa hampir seluruh kandungan UTJ lebih kecil dari pada nilai primitive mantle (Sun dan McDonough, 1989). Pola penurunan UTJringan menuju UTJ-menengah (medium$R E E$ ) yang kemudian menaik kembali menuju UTJ-berat terungkap pada diagram 
laba-laba Profil Andowia. Pola kandungan UTJ yang berbeda diperlihatkan oleh Profil Wawolimbue-Marombo UTJ-ringan naik secara bertahap menuju UTJ-berat. Lebih jauh, kesamaan pola tiga horizon KUR 158 dan satu horizon KUR 157 membuktikan bahwa kedua lokasi pelapukan berasal dari batuan induk yang sama.

Anomali negatif $\mathrm{Ce}$ terdapat pada horizon saprolit (KUR 57-C, KUR 57-D, dan KUR 157) maupun top soil (KUR 57-A dan KUR 158) pada kedua stasiun pengamatan. Sebaliknya, Ce justru memiliki anomali positif pada horizon laterit di Andowia maupun Wawolimbue. Selama pelapukan pada iklim tropis maupun dalam proses pelarutan mineral, terjadi mobilisasi dan migrasi UTJ yang kemudian akan terabsorbsi pada mineral lempungan (Marker dan Oliveira, 1994). Proses migrasi UTJ relatif tidak terjadi pada unsur Ce akibat oksidasi spontan dari $\mathrm{Ce}^{3+}$ menjadi $\mathrm{Ce}^{4+}$ yang menjelaskan penyebab anomali negatif Ce pada horizon laterit. Keterdapatan anomali negatif $\mathrm{Ce}$ diperkirakan sebagai indikator bijih yang terbentuk melalui absorbsi ion (Maulana dan Kenzo, 2011). Perbedaan kecenderungan anomali Eu dapat dijadikan pembeda dua profil penelitian, anomali negatif Eu nampak jelas pada keempat conto dari Andowia. Sedangkan, Profil Wawolimbue-Marombo terlihat relatif tanpa anomali Eu. Perbedaan ini menunjukkan bahwa kemungkinan besar batuan induk kedua profil ini berbeda untuk menguatkan kesimpulan Irzon dan Baharuddin (2016) yang membagi batuan ultramafik di Konawe Utara terbagi menjadi kelompok olivine-hornblende-piroksenit dan kelompok Iherzolit.

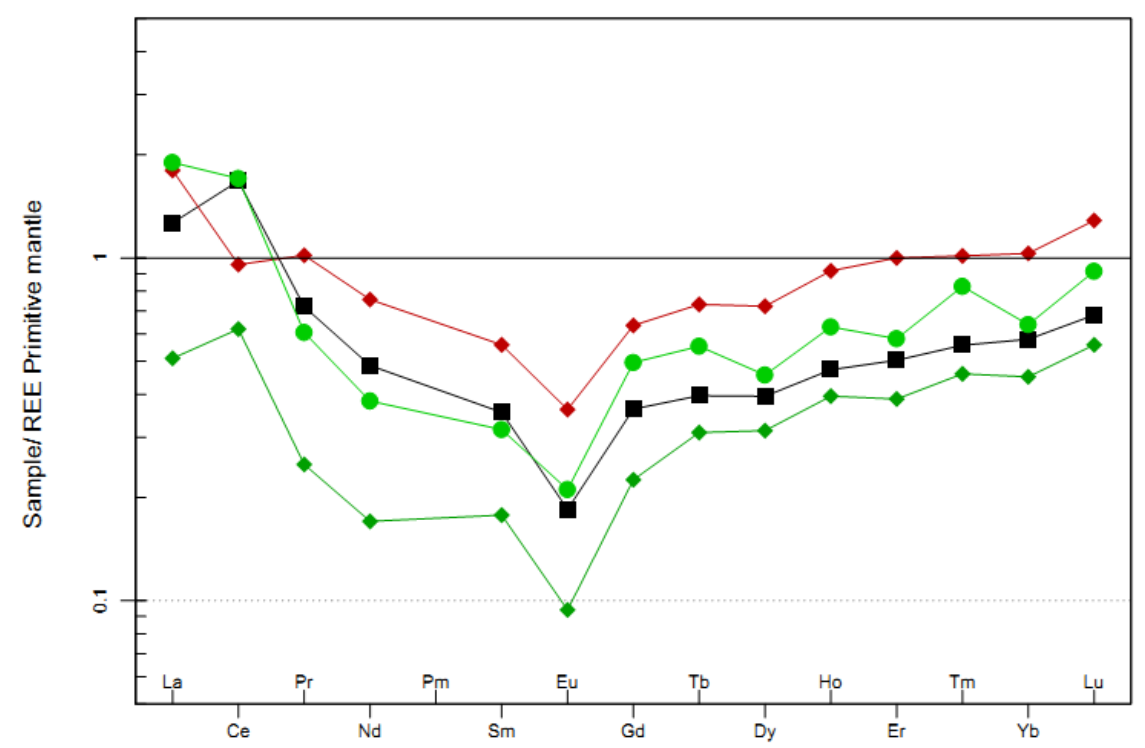

Gambar 8. Diagram laba-laba unsur tanah jarang Profil Andowia.

Normalisasi terhadap primitive mantle value (Sun dan McDonough, 1989).

$=$ KUR 57-D, =KUR 57-C, =KUR 57-B, dan = KUR 57-A. 


\section{MAKALAH ILMIAH}

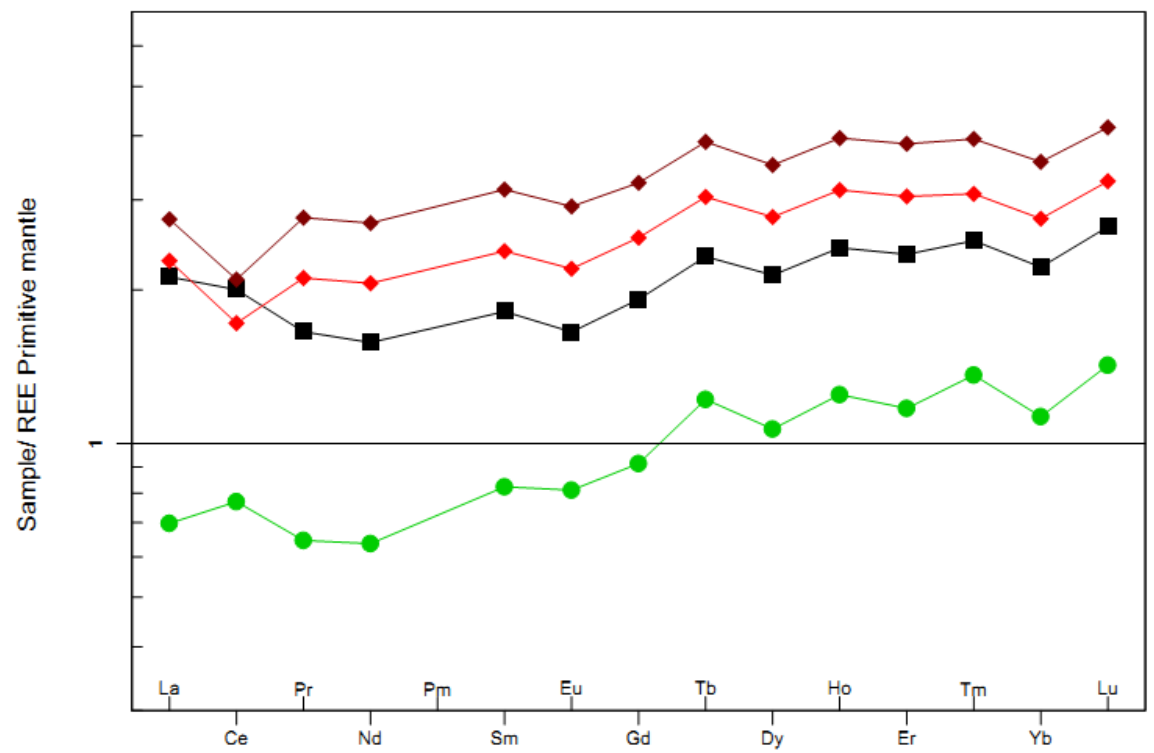

Gambar 9. Diagram laba-laba Profil Wawolimbue-Marombo.

Normalisasi terhadap primitive mantle value (Sun dan McDonough, 1989).

$=$ KUR 157, = KUR 158-C $>=$ KUR 158-B, dan = KUR 158-A.

\section{KESIMPULAN}

Kondisi iklim tropis menjadi faktor penting terkait laju pelapukan di Indonesia yang memungkinkan untuk dipelajari dari berbagai segi. Unsur-unsur pada batuan induk termobilisasi kembali melalui proses pelapukan. Pengayaan logam berat: $\mathrm{Mn}, \mathrm{Cr}$, $\mathrm{Ti}$, dan To terbukti terjadi berbanding lurus dengan proses pelapukan di kedua titik pengamatan di Konawe Utara. Meski demikian, $\mathrm{Si}, \mathrm{Mg}$, dan $\mathrm{Ca}$ tampak berkurang dari horizon yang relatif paling segar menuju horizon paling lapuk. $\mathrm{Ni}$ terdeteksi terkonsentrasikan pada transitional bedrock. Dengan demikian dapat disimpulkan bahwa pengayaan logam-logam berat telah terjadi pada horizon laterit dari profil dalam penelitian ini. Kesimpulan tersebut dapat dijadikan dasar untuk mengarahkan eksplorasi logam nikel dan paduan besi pada wilayah dengan horizon laterit yang tebal. Perbedaan batuan induk Profil Andowia dengan Profil Wawolimbue-Marombo ditunjukkan melalui ketidaksamaan pada pola diagram laba-laba unsur tanah jarang.
Diagram tersebut juga mempertegas bahwa walau lokasi Wawolimbue terpisah $1,4 \mathrm{~km}$ dari lokasi Marombo, kedua profil berasal dari batuan induk serupa. Unsur tanah jarang terkonsentrasikan pada horizon laterit dibandingkan dengan horizon lainnya. Anomali Ce negatif terjadi akibat oksidasi spontan dari $\mathrm{Ce}^{3+}$ menjadi $\mathrm{Ce}^{4+}$ sehingga mobilisasi UTJ menuju horizon laterit tidak diikuti oleh unsur tersebut.

\section{UCAPAN TERIMA KASIH}

Studi ini sepenuhnya didukung oleh program Pusar Survei Geologi di Kabupaten Konawe Utara pada tahun 2014. Penulis ingin mengucapkan terimakasih kepada Kepala Pusat Survei Geologi atas izin publikasinya. Bapak Baharuddin dan Bapak Purnama Sendjaja telah membuka lebar cakrawala kebumian wilayah Sulawesi Tenggara berikut pemahaman mengenai lateritisasi. Bapak Kurnia, Ibu Irfanny Agustiani, Saudari Indan dan Saudari Citra telah mengawal hasil analisis geokimia dengan baik. Tidak lupa saya berterimakasih kepada Bapak Ayeng Hikmat dan Bapak Iwan Rudiawan terkait penggunaan data geologi. 


\section{DAFTAR PUSTAKA}

Ahmad, W., 2006. Nickel Laterites: Fundamental of chemistry, mineralogy, weathering process, formation and exploration, Tidak dipublikasikan, PT. INCO, $207 \mathrm{p}$.

Alam, S., Sunarminto, B.H. dan Siradz, S.A., 2012. Karakteristik Bahan Induk Tanah dari Formasi Geologi Kompleks Ultramafik di Sulawesi Tenggara. Jurnal Agroteknos, v.12(2), pp. 122120.

Anonim, 2013. Sulawesi Tenggara dalam Angka. Badan Pusat Statistik Provinsi Sulawesi Tenggara, pp.3-9.

Bao, S.X., Zhou, H.Y., Peng, X.T., Ji. F.W. dan Yao, H.Q., 2008. Geochemistry of REE and yttrium in hydrothermal fluids from the Endeavour segment, Juan de Fuca Ridge, Geochemical Journal, 42, pp. $359-370$.

Brown, E.T., Bourles, D.L., Colin, F., Sanfo, Z., Raisbeck, G.M. dan Yiou, F., 1994. The development of iron crust lateritic systems in Burkina Faso, West Africa examined with in-situ-produced cosmogenic nuclides, Earth and Planetary Science Letters, 124, pp. 1933.

Calagari, A.A., Farahani, F.K., dan Abedini, A., 2015. Geochemical Characteristics of a laterite: The Jurassic Zan Deposit, Iran. Acta Geodynamica et Geomaterialia, 12(1), pp.6777.doi:10.13168/AGG.2015.0001.

Castor, S.B. dan Hedrick, J.B., 2006. Rare earth elements', in Kogel, et al., eds., 2006, Industrial Minerals \& Rocks, 7th edition, Society for Mining, Metallurgy, and Exploration, Inc., pp. 769-792.

Chaerul, M., Pallu, M.S., Selintung, M. dan Patanduk, J., 2015. Distribution and Mobility of Heavy Metal Materials in Settling Ponds Post Laterite Nickel Mining (A Case Study: North Motui Konawe, Southeast Sulawesi)'. International Journal of Engineering Research and Applications, 5(6-2), p.72-75.doi: $\quad$ 10.1007/s11631-0140686-y.

Charlton, T.R., 2000. Tertiary evolution of the Eastern Indonesia Collision
Complex'Journal of Asian Earth Sciences, 18, pp.603-631.

Gao, J.M., Yan, Z.K., Liu, J., Zhang M. dan Guo, M., 2014. A novel hydrometallurgical approach to recover valuable metals from laterite ore. Hydrometallurgy, 150, pp.161-166.

Hariri, M.M., 2004. Petrographical and Geochemical Characteristics of the Ultramafic Rocks of Jabal Zalm, Central Arabian Shield, Saudi Arabia. The Arabian Journal for Science and Engineering, 29(2A), pp.123-133.

Heggie, G.J., Barnes, S.J. dan Fiorentini, M.L.,2013. Application of lithogeochemistry in the assessment of nickel-sulphide potential in komatiite belts from northern Finland and Norway. Bulletin of the Geological Society of Finland, 85, pp. 107-126.

Irzon, R., Syafri, I., Hutabarat, J., dan Sendjaja, P., 2016. REE Comparison between Muncung Granite Samples and their Weathering Products, Lingga Regency, Riau Islands. Indonesian Journal on Geoscience, 3(3), pp.149161.doi: 10.17014/ijog.3.3.149-161.

Irzon, R. dan Baharuddin, 2016. Geochemistry of Ophiolite Complex in North Konawe, Southeast Sulawesi, Eksplorium, 37(2), pp.101-114.

Jainwu, L., Ganlin, Z., dan Zitong, G., 2014. Mobilization and redistribution of elements in soils developed from extreme weathering basalt on Hainan Island, Chinese Journal of Geochemistry, 33, pp.262-271.doi: 10.1007/s11631-014-0686-y.

Kumar, A. dan Maiti, S.K., 2013. Availability of Chromium, Nickel and Other Associated Heavy Metals of Ultramafic and Serpentine Soil /Rock and in Plants, International Journal of Emerging Technology and Advanced Engineering, 3(2), pp.256-268.

Marker, A., dan de Oliveira, J.J., 1994. Climatic and morphological control of rare earth element distribution in weathering mantles on alkaline rocks, Catena, 21, pp.179-193.

Mustapha, A.M. dan Alhassan, M.,2012. Chemical, Physico-chemical and Geotechnical Properties of Lateritic 


\section{MAKALAH ILMIAH}

Weathering Profile Derived from Granite Basement, Electronic Journal of Geotechnical Engineering, 17(J), pp.1505-1514.

Purwanto, H.S. dan Agustini, S., 2014. Lateritisasi Nikel Pulau Pakal, Kabupaten Halmahera Selatan Provinsi Maluku Utara, Jurnal IImiah MTG, 7(1).

Ratie, G., Jouvin, D., Garnier, J., Olivier, R., Miska, S., Guimaraes E., Cruz, V.L., Sivry, Y., Zelano, I., Pelletier, M.E., Thil, F. dan Quantin, C., 2015. Nickel isotope fractionation during tropical weathering of ultramafic rocks, Chemical Geology, 402, pp.68-76.

Rusmana, E., Sukido, Sukarna, D., Haryono, E., dan Simandjuntak, T.O., 1993. Geology of the Lasusua - Kendari Quadrangle, Sulawesi, Geological Research and Development Centre, Bandung.
Sagapoa, C.V., Imai, A. dan Watanabe, K., 2011. Laterization Process of Ultramafic Rocks in Siruka, Solomon Island, Journal of Novel Carbon Resources Sciences, 3, pp.32-39.

Sun, S.S. dan McDonough, W.F., 1989. Chemical and isotopic systematics of oceanic basalts: implications for mantle composition and processes, Geological Society, London, Special Publications, 42, pp.313-345.

Syafrizal, Anggayana, K., dan Guntoro, D., 2011. Karakterisasi Mineralogi Endapan Nikel Laterit di Daerah Tinanggea Kabupaten Konawe Selatan. Sulawesi Tenggara, Jurnal Teknologi Mineral, 18(4), pp.211-220.

White, W.M., 2011. Geochemistry, Chapter 7: Trace Elements in Igneous Process. Wiley-Blackwell, Chicester, pp.268318.

\begin{tabular}{|ll|}
\hline Diterima & $:$ 5 Juli 2017 \\
Direvisi & $:$ 11 Agustus 2017 \\
Disetujui & $:$ 29 Agustus 2017 \\
\hline
\end{tabular}

